\title{
Breeding and Larval Rearing of Asian Moon Scallop Amusium pleuronectes in Eastern Samar, Philippines
}

\author{
Nonita S. Cabacaba ${ }^{1,2, \star}$ Ed-Marie B. Boiser ${ }^{1}$, Kimberly A. Badocdoc ${ }^{1}$, and Cristan Joy M. Campo ${ }^{1}$ \\ ${ }^{1}$ National Fisheries Research and Development Center - Marine Fisheries Research and Development Center \\ (NFRDI-MFRDC) \\ ${ }^{2}$ Bureau of Fisheries and Aquatic Resources - Guiuan Marine Fisheries Development Center \\ (BFAR-GMFDC), Guiuan, Eastern Samar 6809
}

\begin{abstract}
A B S T R A C T
Asian moon scallop, Amusium pleuronectes, is among the most common commercially harvested scallop in the Philippines. This study investigated suitable conditioning methods, induced spawning, and documented scallop larval development at the Marine Fisheries Research and Development Center (MFRDC) Guiuan, Eastern Samar. Scallops held in tanks with flow-through water system without substrate yielded high survival rate of $48.06 \pm 5.95 \%$. Optimum water temperature was $28-29^{\circ} \mathrm{C}$ for maintaining scallops. Isochrysis galbana and Chaetoceros calcitrans were suitable microalgal feed for A. pleuronectes consumed at 7,388,888 cells min ${ }^{-1}$ per scallop. These significant results were applied in maintaining scallops at the hatchery. As a result, scallops with an average $19.8 \mathrm{~mm}$ shell length (SL) reached $37.5 \mathrm{~mm}$ SL within four months with a survival rate of $96.57 \pm 2.04 \%$, average daily growth rate (ADGR) of $0.13 \pm 0.04 \mathrm{~mm}$.day ${ }^{-1}$, and specific growth rate (SGR) of $3.92 \pm 1.31 \% \cdot \mathrm{d}^{-1}$. Natural spawning was successful under controlled conditions while induced spawning trial through thermal stimulation, food shock, sexual stimulation, and serotonin injection resulted unsuccessful release of sperm and eggs. The estimated number of fertilized eggs per spawning ranged from 0.22-1.4 million. Fertilized eggs appeared spherical and dark in color with 54.2-62.57 $\mu \mathrm{m}$ in diameter. After nine hours, the larvae developed into trochophore stage with 59.08-84.4 $\mu \mathrm{m}$ in length. D-veliger with $120.37-157.07 \mu \mathrm{m}$ shell length developed after 24 hours. Development of the early umbone stage was reached on day 5; and on day 7, the umbo larvae become well-developed with shell length of $135.45-173.36 \mu \mathrm{m}$. On day 9, pedi-veligers were observed in the culture. Spat grew 312.41-509.48 $\mu \mathrm{m}$ on day 16 and survived until four months with final shell length of 4-10 mm. For the larval rearing, stocking density of $A$. pleuronectes larvae observed highest survival rate of $0.04 \pm 0.03 \%$ at 200 larvae/L, while no larvae survived at 800 larvae/L due to contamination of protozoans in the culture medium.
\end{abstract}

${ }^{\star}$ Corresponding Author: nitz_sur@yahoo.com

Received: August 1, 2019

Accepted: May 15, 2020
Keywords:

Amusium pleuronectes, conditioning methods, spawning, larval development

\section{I N T R O D U C T I O N}

$A$ musium pleuronectes is a bivalve species which belongs to the Pectinidae family and commonly known as Asian moon scallop. It has thin, smooth, biconvex white and brown colored valves. A. pleuronectes lies recessed in the substrate, the white colored valve positioned lying on the seabed while brown colored valve is on top and the umbonal region is submerged in the substrate (Morton 1980).
This species naturally occur in soft substratum such as sandy-mud to muddy bottom at a depth of 18-40 meter (Gabral-Llana 1980; Del Norte 1988) where it feeds on phytoplankton, detritus, and other suspended particulates. Within two-year period, it can rapidly grow up to $106 \mathrm{~mm}$ shell length (Belda and Del Norte 1988; Del Norte 1988) and reach sexual maturity at a shell length of $54 \mathrm{~mm}$ (Gabral-Llana 1980). The spawning of $A$. pleuronectes was observed all year round with peaks during the colder months at 
temperatures ranging 24.6 to $26^{\circ} \mathrm{C}$ (Llana and Aprieto 1980; Del Norte 1986).

Asian moon scallop has a very wide distribution, being recorded from the Indo-Pacific countries like Ryuku Islands of southern Japan, China, Thailand, and Indonesia (Habe 1964). In the Philippines, A. pleuronectes has been reported to occur in Lingayen Gulf (Del Norte 1986) and Visayan Sea (Llana 1983). It is also found in Eastern Visayas and locally known as "tipay" (Cabacaba and Salamida 2017, unpublished).

In Eastern Visayas, A. pleuronectes is a commercially important species. The adductor muscles are basically traded for consumption and shells are utilized as raw materials for handicraft production. The fresh shell meat produced is sold to Metropolis such as Ormoc, Tacloban, and Cebu's seafood restaurants for 100-200 pesos per kilo and shells were utilized for decoration ornaments and souvenir items in the region. Because of increasing demand for scallops, trawl gears are used to maximize the collection (Cabacaba and Salamida 2017, unpublished).

Based on the study of Cabacaba and Salamida (2017, unpublished) conducted in Eastern Visayas, this species is primarily harvested through bottom trawling by the use of trawl gear or the "baby trawl" in commercial and municipal waters. Trawl gears are active gears that is characterized by the pursuit of the target species by towing or dredging. Bottom trawling and the frequent discarding of non-target sizes and species both of fish and non-fish species threatens the seabed ecosystem (FAO 2001). Likewise, high unregulated trawl fishing consequently leads to overfishing, depletion of the resource, and eventual loss of species diversity (Bobiles and Soliman 2018). Thus, this fishing practice is now banned by the amended Philippine Fisheries Code Republic Act 10654.

To provide an alternative solution about the banning of trawl gears, scallop aquaculture has been established to support production and sustainability of scallop stocks. In the Philippines, no farming attempt has been reported; however, interests about the scallop species Amusium pleuronectes have been previously observed. There are published works that have been reported and these were mainly about the population dynamics, spawning, breeding, and culture of the commodity (Llana 1983; Llana and Aprieto 1980; Del Norte 1988; Belda and Del Norte 1988; Chaitanawisuti and Menasveta 1992; Rice et al. 1994; Wang et al. 2009; Cabacaba and Salamida 2017, unpublished).
Recently, there has been an interest in the cultivation of Amusium pleuronectes because of its relatively fast growth and utilization of low food chain phytoplankton, detritus, and other suspended particulates (Rice et al. 1994). To address that interest, this study was conducted to determine the applicability of breeding and larval rearing of A. pleuronectes in Guiuan, Eastern Samar. The determination of conditioning methods, spawning technique, early development stages, and larval rearing are essential for the hatchery operation of Amusium pleuronectes. Therefore, this study also aims to contribute to the growing knowledge necessary for the hatchery rearing of commercially important scallops. Moreover, the technology on aquaculture of Amusium plueronectes will serve as a solution to the sustainability of scallop in the fishery industry as total implementation of the banning of trawl gears will be strengthened.

\section{MATERIALS AND METHODS}

This study was conducted at the Marine Fisheries Research and Development Center (MFRDC), Brgy. Sto. Niño, Guiuan, Eastern Samar. Materials and facilities used for the setup of experiments were composed of filtered seawater lines, conditioning tanks and plastic containers, aeration system, and a laboratory space equipped with a microscope for counting, monitoring, and data collection. For the larval rearing, the use of different size of sieves are necessary for the collection of larvae. The sieves vary in size from $40 \mu \mathrm{m}-120 \mu \mathrm{m}$ depending on the developmental stages of scallop.

\subsection{Microalgal Culture}

Microalgae Tetraselmis sp., Chaetoceros calcitrans, and Isochrysis galbana were initially grown and collected at the Phycology laboratory of the Bureau of Fisheries and Aquatic Resources - Guiuan Marine Fisheries Development Center (BFAR-GMFDC), Guiuan, Eastern Samar. Cylindrical transparent tanks with 100-L capacity were used for the mass culture of microalgae. Starter culture $(8 \mathrm{~L})$ of microalgae Tetraselmis sp. Chaetoceros calcitrans and Isochrysis galbana from the phycology laboratory were scaled-up to 50 liters in an outdoor culture system at the hatchery prior to feeding of scallops and larvae. Mass cultured microalgae were ready to harvest after three consecutive days of culture. 


\subsection{Collection of Amusium pleuronectes}

Amusium pleuronectes were collected at the Biliran Strait and Leyte Gulf (Figure 1) through the use of trawl gears. Monthly collection was done to secure enough number of scallops to be used in conditioning experiments and as broodstock for spawning. Scallops collected from the trawl gears were kept alive in plastic bags (8-10 scallops per bag) with approximately 2 liters of seawater and inflated to full capacity with pure oxygen. The plastic bags were placed in styrofoam fish transport boxes for over-land transport to the study site at the MFRDC. The scallops were evaluated to classify its gonad stages and determine its size. The size (shell length) of Amusium pleuronectes were measured from the dorsal hinge to the ventral margin of the shell using a caliper with graduation of $0.01 \mathrm{~mm}$. Gonad stages were classified by opening the valves wide enough to allow visual grading of the gonad without sacrificing the animals. Scallops identified as mature have bulgy/full, bright orange ovary, and creamcolored testes (Appendix B, Figure 8). Scallops in spawning stage have hollow "channels" on the surface of the gonad, which appear shrunken. Those that are in spent stage, their gonads appear dull, sunken, and flaccid. After the classification, mature scallops were used as broodstock and tested for experimental spawning technique trials, while non-mature scallops were subjected to experimental conditioning set-ups at the hatchery in MFRDC.

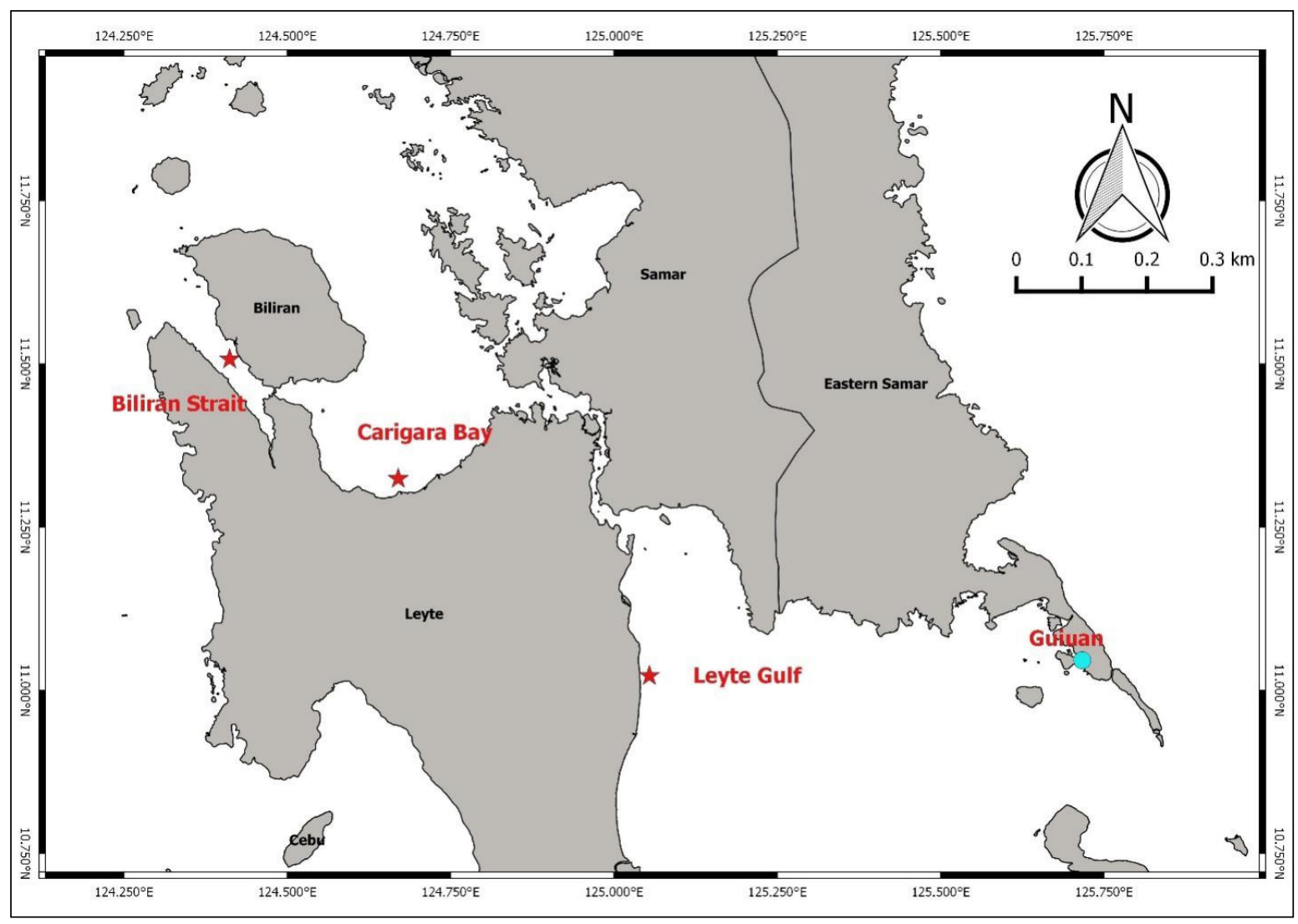

Figure 1. Collection sites of Amusium pleurunectes in Eastern Visayas.

2.3 Experimental set-ups on conditioning methods for Amusium pleuronectes

Difficulties in obtaining ripe broodstock from the wild populations in Leyte Gulf and Biliran Strait prompted the development of hatchery conditioning protocols. Conditioning methods such as holding technique, holding temperatures, microalgal diets, and clearance rates of individual scallop favorable for survival were identified. Then, significant findings from the previously mentioned conditioning methods were applied to scallops maintained in the hatchery in order to assess its effectiveness in terms of growth, survival, and gonad development. 
Experiment I: Different holding systems for A. pleuronectes.

The healthy stocks collected from the wild population were transported and kept in the hatchery to ensure suitable condition ready for spawning. To evaluate suitable holding techniques, experimental set-up included two holding systems: a.) Flow-through water system with muddy substrate; and b.) Flowthrough water system without substrate. The substrate used prior to the experiment underwent a series of sun drying and washing to ensure minimal contamination and eliminate other organisms. A total of 48 A. pleuronectes with shell length of 31-52 $\mathrm{mm}$ from the same batch of collection were randomly chosen for the experiment. Scallops were kept in an aerated 100 -L round flat-bottom plastic containers filled with filtered seawater and maintained at a temperature of $28-29^{\circ} \mathrm{C}$ and salinity of $34 \mathrm{ppt}$. Three replicates in each treatment group were set up containing eight scallops. The scallops were supplemented daily with 2 liters of either I. galbana, C. calcitrans, or Tetraselmis $s p$. every morning and afternoon. During feeding, flow-through were temporarily turned off for about an hour or until microalgae diets were consumed, to prevent the microalgae from escaping. Monitoring and maintenance involved cleaning and daily removal of fecal materials or dead scallops usually prior to feeding. After the eight-week period, assessment for the survival rate of $A$. pleuronectes was conducted.

Experiment II: Different holding water temperatures for A. pleuronectes.

Establishing the optimum temperature was also seen as a critical step in obtaining and ensuring survival of $A$. pleuronectes in the hatchery. In this study, different water temperatures of $26-27^{\circ} \mathrm{C}$ (ambient temperature at the collection site), $28-29^{\circ} \mathrm{C}$ (ambient temperature in Guiuan), and $30-31^{\circ} \mathrm{C}$ (above ambient temperature) were tested. The experimental temperature under $26-27^{\circ} \mathrm{C}$ was attained by a static water system. For the water temperature under 28$29^{\circ} \mathrm{C}$, flow-through water system has been set-up, and the $30-31^{\circ} \mathrm{C}$ set-up was achieved by the use of a heating device. A total of $27 \mathrm{~A}$. pleuronectes with shell length ranging $69-83 \mathrm{~mm}$ were used in the experiment. Prior to experimentation, visual grading of gonad stages of scallops was conducted in order to serve as a basis of possible gonadal development within the period. Each temperature treatment contained 3 scallops which were held individually in a $10 \mathrm{~L}$ aquaria without substrate. The temperature treatments were triplicated, and the $10 \mathrm{~L}$ aquarium were placed inside a $1 \times 1 \times 0.33 \mathrm{~m}$ wooden tanks (water bath) for 8 weeks. The scallops were fed twice daily in the morning and afternoon with $2 \mathrm{~L}$ of $I$. galbana and C. calcitrans at 10,000-15,000 cell per ml. Then after every feeding, wooden tanks were covered with black net to regulate the desired temperatures and minimize activity of scallop due to exposure of light. After 8 weeks of maintenance, scallops were evaluated for survival rate and gonad changes.

Experiment III: Different microalgae diets for holding A. pleuronectes.

The experiment on the determination of clearance rate of scallops was conducted following the previous work of Rice et al. (1994); however, different microalgae diets were used in this study. Clearance rates of individual scallop per experimental diets were determined by monitoring depletion of microalgae species from the medium. The microalgae diets used in the experiment were lsochrysis galbana, Tetraselmis sp., and Chaetoceros calcitrans.

A total of nine scallops with shell length of $60-70 \mathrm{~mm}$ were stocked in $10-\mathrm{L}$ aerated static aquarium at $28-29^{\circ} \mathrm{C}$. Prior to the experiment, all scallops were starved for 24 hours in order to fully digest all food item in their gut and allow the release as fecal materials. After 24 hours, feces and pseudofeces were removed while replacing old seawater with new filtered seawater. Then, total algal concentration of $2.28 \times 10^{9}$ cells of microalgae (approximately $2 \mathrm{~L}$ per scallop) was added to the aquarium containing the scallops.

Monitoring of depletion of microalgae diets in the water was done by taking $1 \mathrm{~mL}$ water samples every $2 \mathrm{~h}, 4 \mathrm{~h}, 6 \mathrm{~h}, 8 \mathrm{~h}, 10 \mathrm{~h}$ and $24 \mathrm{~h}$ from each of the aquarium. These samples were brought to microscopy room and was counted using a hemacytometer. At the completion of experiment, fecal samples were collected and examined under microscope at $100 \mathrm{x}$ magnification to evaluate the degree of digestion of algal cells. Lastly, clearance rate was calculated by the equations of Jorgensen (1943) or Coughlin (1969) as cited by Rice et al. (1994), and expressed as mL per min or cells filtered per unit time: 


$$
\begin{aligned}
& \mathrm{F}=\mathrm{V}\left[\ln \left(\mathrm{C}_{0} / \mathrm{C}_{\mathrm{t}}\right) / \mathrm{t}\right] \\
& \text { where, F - the filtration rate in } \\
& \text { ml.hour }{ }^{-1} \\
& \mathrm{~V} \quad \text { - the volume of the experimental } \\
& \text { vessel in } \mathrm{ml} \text {, } \\
& \ln \left(\mathrm{C}_{0} / \mathrm{C}_{\mathrm{t}}\right) \text { - the natural log of the cell } \\
& \text { concentration at time zero } \\
& \text { divided by the concentration; } \\
& \mathrm{t} \quad \text { - time in hours }
\end{aligned}
$$

Experiment IV: Conditioning of A. pleuronectes

Conditioning of $A$. pleuronectes was attempted using protocols based on the findings of previous experiments. Experimental animals used in the experiment were small scallops measuring 18-23 $\mathrm{mm}$ shell length. These scallops were placed in a 1-ton fiberglass tank filled with 250 liters filtered seawater and provided with moderate aeration. The tanks were covered with black net since scallops respond to light and vibration by closing their shell valves and drawing in their mantles. The set-ups were placed in a separate and isolated area to avoid frequent disturbances such as sound of the water pump and power blower engines. This was done to lessen the disturbance they receive and allow more time spent on feeding.

This experiment assessed the growth and survival of scallops using the significant results from the experimental conditioning methods (optimum water temperature, suitable algal concentration of microalgae given, and appropriate holding method in the hatchery). Specifically, the water temperature was maintained at $28-29^{\circ} \mathrm{C}$. These scallops were fed twice daily to satiation at algal concentration of $2.28 \times 10^{9}$ cells per scallop (approximately 2 liters of microalgal diet) as determined in the experiment of clearance rate. The best mixed algal species Isochrysis galbana and Chaetoceros calcitrans were given to scallops equally at $570,000 \mathrm{cells} / \mathrm{ml}$. At monthly interval, scallops were assessed for growth and survival. The growth of the scallops were determined using average daily growth rate (ADGR) and specific growth rate (SGR) which can be calculated through the following formulae:

$$
\begin{aligned}
& \mathrm{ADGR}=\frac{\text { final length }- \text { initial length }}{\text { No. of days interval }} \\
& \mathrm{SGR}=\frac{\ln (\text { final length }) \text {-ln(initial length }}{\text { No.of days interval) }} \times 100 .
\end{aligned}
$$

The survival rate was determined using the following formula:

Survival rate $=\frac{\text { total number of individuals survived }}{\text { total no.of individuals initially stocked }} \times 100$

\subsection{Spawning of A. pleuronectes}

The selection of broodstock used for spawning trial should consider a well-formed shell with complete mantles extending to the shell margin and plump healthy-looking soft tissue (Appendix B, Figure 9). Larger scallops produce more eggs, thus a good size of shell length $80-90 \mathrm{~mm}$ were used. In this study, several spawning techniques were observed and tested using different methods such as food shock, thermal stimulation, sexual stimulation, and serotonin injection. On the other hand, observation of natural spawning for A. pleuronectes was also conducted at the hatchery during days of full or new moon.

\section{a. Food Shock}

The use of microalgae for food stimulation in induced spawning of bivalve species was tested based on the study of Breese and Robinsons (1981). In this study, eight hermaphroditic mature scallops (shell length $84-87 \mathrm{~mm}$ ) were placed in a clear round tank filled with $20 \mathrm{~L}$ filtered seawater and provided with moderate aeration. Amusium pleuronectes were induced to spawn by adding excessive amount of microalgae to the holding tank. Twenty (20) liters of either I. galbana or C. calcitrans with a dense concentration of $6.0 \times 109$ cells were given to the broodstock scallops. Scallops were bathed in the tanks with microalgae for 45 minutes. After 45 minutes, scallops were transferred to another clear round tank with $10 \mathrm{~L}$ filtered sea water for observation of possible spawning activity.

\section{b. Thermal Stimulation}

Based from the study of Belda and Del Norte (1988), thermal stimulation was done by raising the temperature of the water by $10^{\circ} \mathrm{C}$ from ambient temperature of about $27^{\circ} \mathrm{C}$. However, results from this study was not successful. In this experiment modification was made, scallops were exposed to temperature cycles wherein water temperature from ambient $24^{\circ} \mathrm{C}$ was increased gradually up to $30^{\circ} \mathrm{C}$ over a period of 6 hours. Initially, Amusium plueronectes were placed individually in $10 \mathrm{~L}$ aerated aquaria and preconditioned at $24^{\circ} \mathrm{C}$ for 24 hours. 
After preconditioning, temperature cycling was done by gradual increase of the water temperature using a water heater. Once the temperature reached $30^{\circ} \mathrm{C}$, the water heater was constantly set and maintained for 45 minutes. Within 45 minutes, scallops were observed for possible release of either sperm or egg. However, failure of spawning warranted further cycle of temperature adjustment. This was done by adding pre-cooled water into the container holding the broodstock scallop. Then, water temperature was decreased gradually from $30^{\circ} \mathrm{C}$ to $24^{\circ} \mathrm{C}$ at one degree per hour. Four to five temperature cycles was done until spawning or release of sperms and eggs was observed.

\section{c. Sexual Stimulation}

Sexual stimulation was accomplished by introducing freshly emitted spawn, strip, or extract of ripe gonad. Briefly, gonads of hermaphroditic scallops were dissected out and placed in a petri plate with 10 $\mathrm{mL}$ filtered sea water. Gonads were cut up into small chunks and was agitated to release the gametes. The sperm suspension or egg suspension was filtered at 60 $\mu \mathrm{m}$ to remove the large chunks of gonad and diluted into $1000 \mathrm{~mL}$ beaker. Five hundred (500) $\mathrm{mL}$ sperm suspension was added to $60 \mathrm{~L}$ capacity rectangular plastic containers filled with $50 \mathrm{~L}$ seawater containing ten (10) mature scallops. Waiting time of 4-5 hours was allotted for the observation of possible release of sperm or eggs.

\section{d. Serotonin Injection}

A total of five (5) mature scallops were selected for serotonin treatment. In each case, $0.4 \mathrm{~mL}$ of a $3 \mathrm{mM}$ solution was injected into the anterior portion of the abductor muscle and in the gonads of both sexes. Then, each scallop was placed in a white plastic basin filled with $10 \mathrm{~L}$ filtered seawater and moderate aeration. A maximum of 5 hours observation period was allotted for the surveillance of possible spawning activities after the injection of stimuli.

\section{e. Natural Spawning}

Observation of natural spawning was done based on the lunar phase. Timing of collection was conducted prior to the full moon phases or new moon phase of the month at Biliran Strait. Ripe scallops collected from the wild population were stocked in a plastic barrel filled with $100 \mathrm{~L}$ filtered seawater and moderate aeration in static water system. The setup was fully covered with black net to ensure minimal disturbance. If spawning did not occur before or on full moon, continuation of observation was done in three consecutive days after the moon phase. The monitoring of spawning was done every day between $4 \mathrm{am}$ to $5 \mathrm{am}$ in the morning during which successful release of sperms and eggs occur. The fertilization was also indicated by the presence of foamy bubbles on the surface of water in the tank.

\subsection{Embryonic and Larval development of A. pleuronectes}

After successful fertilization, fertilized eggs were collected from the tank using a series of sieves piled from smaller mesh size to larger mesh size $(40 \mu \mathrm{m}-60 \mu \mathrm{m}-120 \mu \mathrm{m})$. Larvae were transferred into the $60 \mathrm{~L}$ incubation tank with minimal aeration. Prior to counting and collection of samples, an improvised plunger was used to mix the water in the incubation tank in order to obtain even distribution of fertilized eggs. The total fertilized egg count was estimated by taking $5 \mathrm{~mL}$ samples from the incubation tank. The fertilized eggs were then distributed into several $100 \mathrm{~L}$ capacity culture vessels. Each culture vessel was filled with $70 \mathrm{~L}$ aerated filtered seawater at stocking density of 500 larvae per liter. The temperature of the cultures ranged from $27^{\circ} \mathrm{C}$ to $28^{\circ} \mathrm{C}$ and salinity was maintained at 33 ppt.

The embryonic and larval development of Amusium pleuronectes was monitored daily in the laboratory. Samples from the culture were taken and examined under microscope at 100x magnification. Using digital camera, photographs of each larval stages were taken for the description of major features of the larval development of $A$. pleuronectes reared in the laboratory. A maximum of 10 samples of larvae were taken daily and measured using digital microscopy. The larvae were given with I. galbana at an initial concentration of 10,000 cells/ml once daily, and increased by 5,000 cells $/ \mathrm{ml}$ on each succeeding day.

\subsection{Larval Rearing: Survival A. pleuronectes larvae in different stocking density}

The purpose of larviculture is to optimize rearing factors and increase production per unit in a limited water volume at minimal cost (Liu et al. 2006). In this study, experiment on stocking density was designed to determine optimal conditions giving the highest survival rates in hatchery culture of Amusium pleuronectes and produce healthy spats. 
To determine the optimal larval density of the scallop Amusium pleuronectes, experiments with the stocking densities of 200, 300, 500, and 800 larvae/L were tested, which included the developmental stages from D-larvae to a one month settled spat. Experimental set-up were carried out in a 60-liter rectangular plastic containers without flow-through, and each treatment group comprised three replicates. During the rearing period, $50 \%$ of seawater was replenished everyday prior to feeding. Water temperature was at $28-29^{\circ} \mathrm{C}$, while salinity was at $34 \mathrm{ppt}$ with continuous supply of aeration. Larvae were fed with Isochrysis galbana every morning and afternoon daily. Concentration of I. galbana were proportionately increased with stocking density to supply larvae in each treatment with the same amounts of microalgal feed (Appendix A, Table 1.)

After one-month stocking, survival rate and shell length of spat were recorded. Larvae were sampled from the bottom of the rectangular plastic containers and survival rate was recorded as percentage of surviving individuals. It is important to handle the spats with care when collecting them since their shells break easily.

\subsection{Data and Statistical Analysis}

Data processing and analysis were conducted using MS Microsoft Excel 2013 and SPSS version 21 programs. Data were presented as means and standard error of the mean in graphs and tables. Significance testing were done using ANOVA and t-test, and Tukey test for post hoc test. Survival rate data were arcsinetransformed prior to statistical analysis. Significance levels for all analysis were set at $95 \%$ confidence interval.

\section{RESULTS AND DISCUSSION}

\subsection{Different Holding Systems}

Results have shown that in flow-through water system without substrate, scallops obtained higher survival rate $(48.06 \pm 5.95 \%)$ compared to scallops maintained in flow-through water system with muddy substrate $(45.49 \pm 3.38 \%)$ (Figure 2$)$ but with no significant difference $(p>0.05)$. This implies that either of the two treatments can be used in holding scallops at the hatchery. According to Helm et al. (2004), the basic methods for broodstock conditioning are much the same for all bivalves. Adults from the sea that were brought in to the hatchery were kept in a best possible condition according to the characteristics of broodstock species. Clams and scallop species are normally buried in substrate at the natural habitat; thus it is maintained in hatchery provided with substrate. On the other hand, species such as oysters and mussels do not require a substrate therefore it is maintained in tanks without substrate.

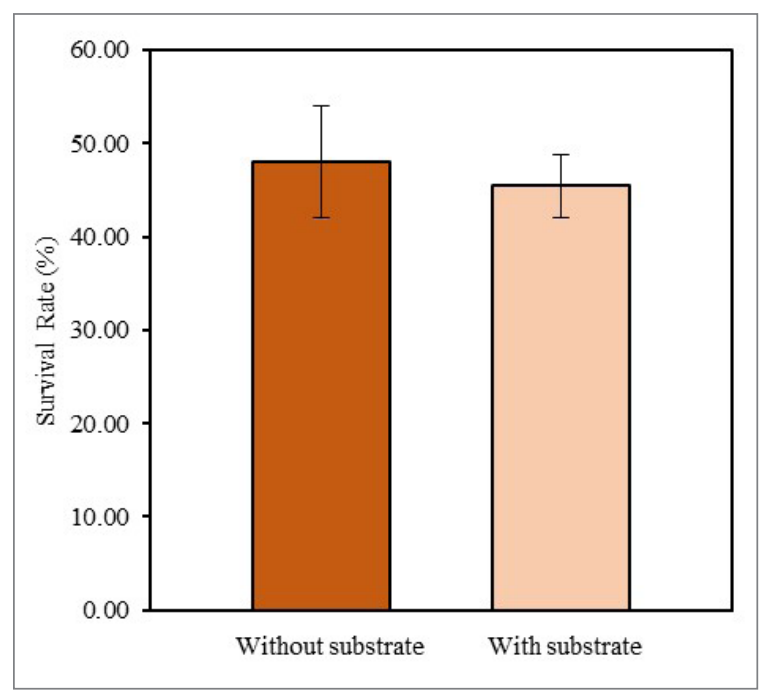

Figure 2. Mean survival rate of $A$. pleuronectes maintained in different holding techniques: flow- through water system with muddy substrate and flow-through water system without substrate.

However, in this study, holding scallops in flow-through water system without substrate has some advantages such as reduced physical handling of scallops, reduced labor demand, and reduced possible dependence on the use of disinfectants to improve water quality. The sediments also caused turbidity upon agitation. On top of all that, cleaning and siphoning fecal materials from the tanks without the toil of removing and washing the sediments daily was also convenient.

\subsection{Different Holding Temperatures}

Figure 3 shows the mean survival rate of Amusium pleuronectes maintained in different water temperatures. ANOVA results have shown that the survival rates of scallops were significantly different among different holding temperatures. A. pleuronectes maintained at $28^{\circ} \mathrm{C}-29^{\circ} \mathrm{C}$ obtained the highest survival $(90 \pm 0.00 \%)$ while the lowest survival $(48 \pm 6.48 \%)$ was observed in the temperature range of $30-31^{\circ} \mathrm{C}$. Furthermore, post hoc test show that there was no significant difference observed between $26-27^{\circ} \mathrm{C}$ and $28-29^{\circ} \mathrm{C}$ holding temperatures. 
Being in the tropics, little variation in seawater temperature and food availability is observed during the year. Thus, the temperature $30-31^{\circ} \mathrm{C}$ is an extreme temperature that caused low survival for Amusium pleuronectes. According to Chaitanawisuti and Menasveta (1992), $30-31^{\circ} \mathrm{C}$ is relatively higher from the ambient temperature $\left(26^{\circ} \mathrm{C}-28^{\circ} \mathrm{C}\right)$ recommended for the tropical species A. pleuronectes. The increased temperature could have caused low survival in scallop due to energy losses associated with active behavior. Amusium pleuronectes are known to be among the most active swimming scallops (Morton 1980) and it is reasonable to expect that interactive energy losses occur in this species as well (Rice et al. 1994). Kinne (1970) suggested that the scallops should be conditioned by lowering the temperature to lower the metabolic activities, and energy is spent on feeding that promotes growth and gamete maturation. Thus, optimum holding temperature for Amusium pleuronectes in the hatchery must not exceed $28-29^{\circ} \mathrm{C}$ and that temperatures range from $26^{\circ} \mathrm{C}-29^{\circ} \mathrm{C}$, which resulted in relatively high survival, was the optimum water temperature in holding scallops in the hatchery.

\subsection{Different Microalgal Diets for holding A. pleuronectes}

The experimental trial on the clearance rate of individual Amusium pleuronectes on the consumption of different species of microalgae is presented in Table 1. Clearance rates of scallops were observed to range from $278.74-446.99 \mathrm{~mL} \cdot \mathrm{min}^{-1}$ for Isochrysis galbana, 267.47-401.21 mL-min ${ }^{-1}$ for Chaetoceros calcitrans, and $69.58-74.50 \mathrm{~mL}-\mathrm{min}^{-1}$ for Tetraselmis $s p$. Moreover, results have shown that the clearance rate of Isochrysis galbana and Chaetoceros calcitrans was not statistically different at $p>0.05$.

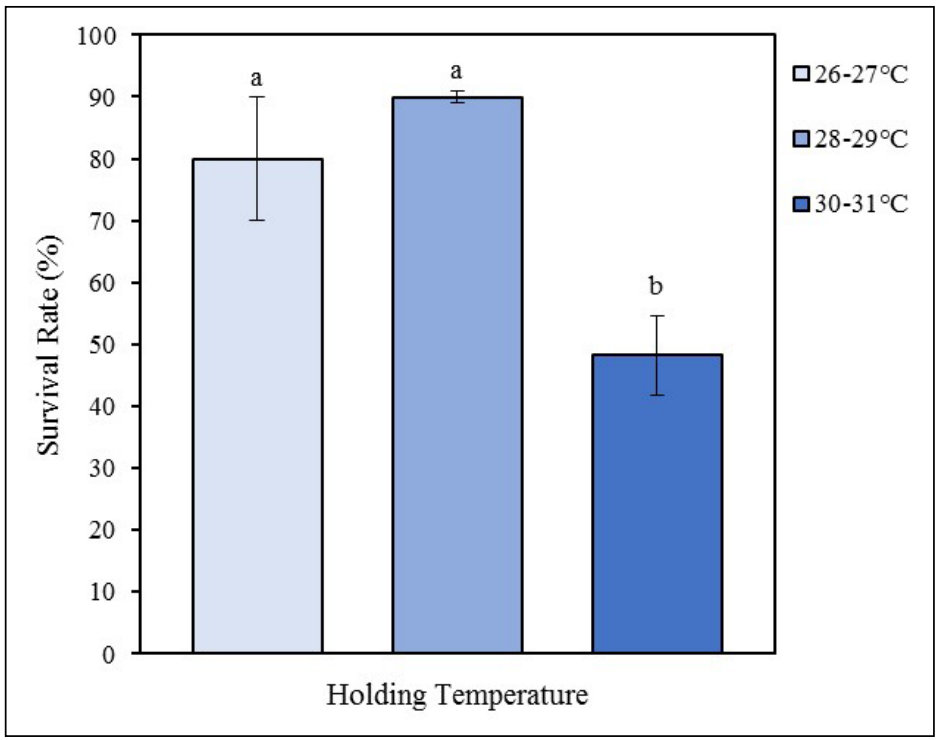

Figure 3. Mean survival rate (\%) of Amusium pleuronectes maintained in different water temperatures: $26-27^{\circ} \mathrm{C}, 28-29^{\circ} \mathrm{C}$, and $30-31^{\circ} \mathrm{C}$. Note: Mean $\pm \mathrm{SE}$ of different water temperature with the same letters show no significant difference $(p>0.05)$.

Table 1. Clearance rate of different microalgae at algal concentration of $2.28 \times 10^{9}$ cells in individual Amusium pleuronectes $(\mathrm{n}=3)$

\begin{tabular}{lccc}
\hline Clearance Rate & I. galbana & C. calcitrans & Tetraselmis sp. \\
\hline Mean clearance rate (ml per min.) & 341.24 & 322.22 & 71 \\
Range clearance rates (ml per min.) & $278.74-446.99$ & $267.47-401.21$ & $69.58-74.50$ \\
Mean clearance rate (cells per min.) & $7,388,888$ & $7,388,888$ & $1,583,333$ \\
\hline
\end{tabular}


The microalgae I. galbana and C. calcitrans were rapidly consumed compared with Tetraselmis sp. Scallops fed with Isochrysis galbana and Chaetoceros calcitrans have a clearance rate of 7,388,888 cells. $\min ^{-1}$, which was significantly higher compared to Tetraselmis sp. (Table 1). After 6 hours, the consumption of the algal cells differed significantly with the algal species Isochrysis galbana, Chaetoceros calcitrans, and Tetraselmis sp. (Figure 4). The number of algal cells consumed after 6-8 hours was greatest in Isochrysis galbana and Chaetoceros calcitrans, and low consumption of Tetraselmis sp., was observed for 24 hours. After 8-10 hours, microalgae species Isochrysis galbana and Chaetoceros calcitrans were almost consumed from the water column as indicated by clearer water in the aquaria, and their cell count was already negligible. The microscopic examination of fecal samples from scallops fed with Tetraselmis sp. revealed the presence of many undigested cells, but not in the case of Isochrysis galbana and Chaetoceros calcitrans $\mathrm{sp}$.

The results in this study indicate that size of food particles was a limiting factor that resulted in relatively poor consumption of microalgae Tetraselmis sp. Additionally, Tetraselmis sp. belongs to the chlorophyte microalgae, which is characterized by a thick cell wall or theca. Thus, poor digestion of Tetraselmis sp. may have resulted from difficulties encountered in digesting the theca of this alga (Epifanio 1979).

Moreover, according to Bricelj and Shumway (1991), the suggested size of food particles with effective retention is about 5-7 $\mu \mathrm{m}$. Likewise, poor retention of food particles with size below $5 \mu \mathrm{m}$ is due to the poor development of the latero-frontal ciliary tracts of scallops. Based from the previous work of Nell and O'Connor (1991), the average cell dimension of Chaetoceros calcitrans is $4 \times 3.1 \mu \mathrm{m}$, Tetraselmis sp. and Isochrysis galbana have $14 \times 8 \mu \mathrm{m}$ and $4 \times 3$ $\mu \mathrm{m}$, respectively (Creswell 2010). Thus, inference of the present study is that Isochrysis galbana and Chaetoceros calcitrans can be used as microalgae diets, and Tetraselmis sp. may not be appropriate as feeding diets for Amusium pleuroenectes.

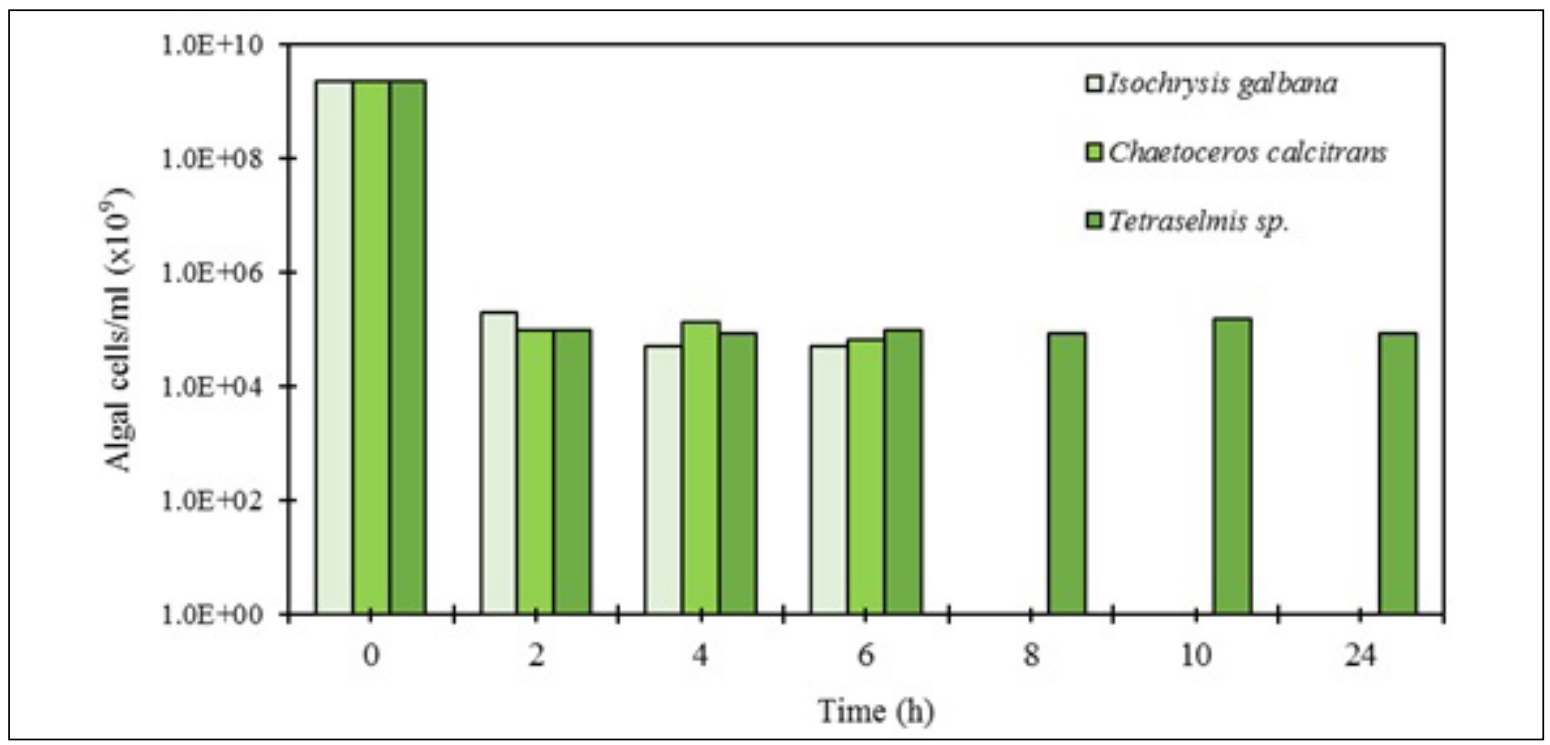

Figure 4. Average algal cells count of Isochrysis galbana, Chaetoceros calcitrans, and Tetraselmis sp. at total algal cell concentration of $2.28 \times 10^{9}$ within 24 hours.

\subsection{Conditioning of $A$. pleuronectes}

Experimental conditioning of Amusium pleuronectes in the hatchery yielded high survival and growth rate under the following conditions: the setup was carried out in tanks without substrate, water temperature maintained at $28-29^{\circ} \mathrm{C}$, and fed equally with Isochrysis galbana and Chaetoceros calcitrans total cell count of $2.28 \times 10^{9}$ cells.
Figure 5 below shows the growth rate of A. pleuronectes in monthly interval. The highest growth rate was observed within four months at 35.7 $\mathrm{mm}$ shell length and survival rate of $96.57 \pm 2.04 \%$. Growth parameters such as average daily growth rate (ADGR) and specific growth rate (SGR) was recorded at $0.13 \pm 0.04 \mathrm{~mm}^{-1 a y^{-1}}$ and $3.92 \pm 1.31 \% \mathrm{~d}^{-1}$ respectively. These results only illustrate the application of the significant conditions based on the previous 
experiments conducted. The data have shown that these conditions (holding technique and microalgae diets and ratio) promote high survival and growth rate of $A$. pleuronectes maintained in the hatchery.

On the other hand, four months stocking of scallops in the hatchery did not guarantee rapid conditioning. Although important hatchery factors such as holding techniques, diet, and ration were determined in this present study, the requirement time of conditioning the scallops in order to reach spawning readiness was not determined. Therefore, conditioning experiments on scallops already undergoing gametogenesis rather than conditioning with sexually undifferentiated scallops warrant future investigation.

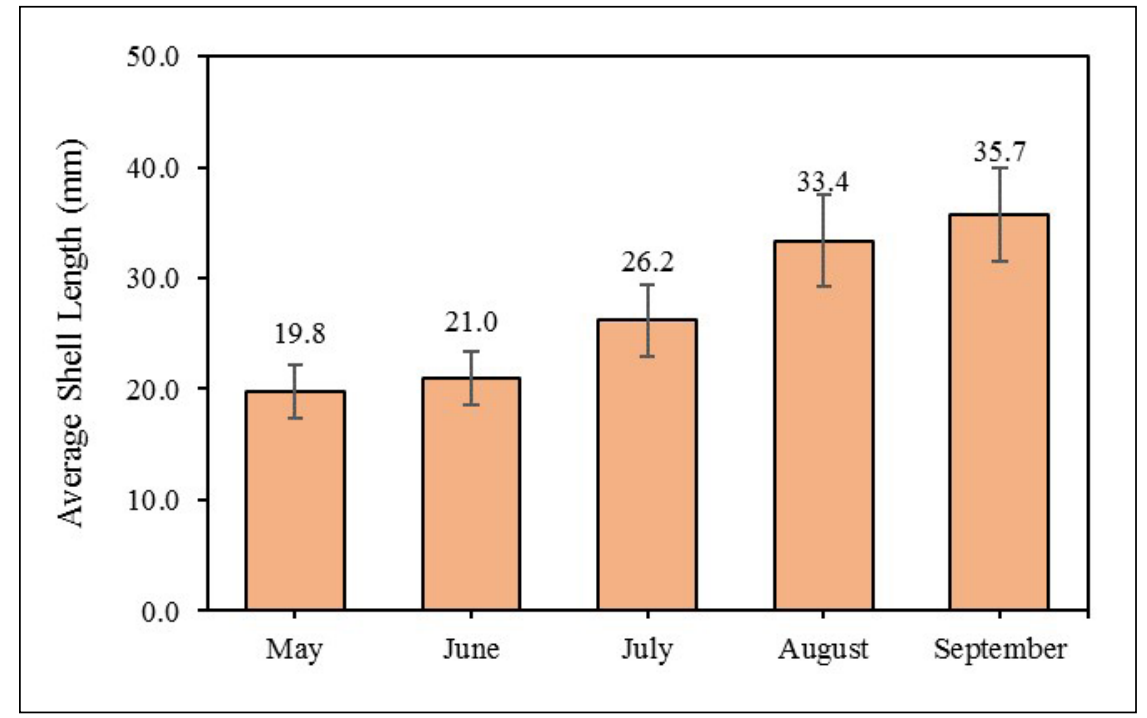

Figure 5. Average shell length (mm) of Amusium pleuronectes from May to September 2017

\subsection{Spawning of A. pleuronectes}

In this study, successful spawning of Amusium pleuronectes was observed naturally in the hatchery, while stimulation methods used such as food shock, thermal stimulation, sexual stimulation, and serotonin injection yielded unsuccessful release of eggs or sperms.

There were four separate natural spawning events from different batches of scallop
(Table 2). Spawning occurred either on, before, or after lunar phases and was easily noted according to the appearance of foamy bubbles on the water surface. Mature scallops exhibited synchronized spawning in every spawning trial. As shown in Table 2, a number of broodstock scallops partially released either sperm or egg while only one or two scallops fully spawned as evident by their empty gonads. The estimated number of fertilized eggs per spawning event ranged from 220,000-1.48 million.

Table 2. Summary of successful spawning of Amusium pleuronectes during April, August, and November 2017.

\begin{tabular}{lcccc}
\hline Date of Spawning & Lunar Phase & Total no. of scallop & $\begin{array}{c}\text { No. of scallop fully } \\
\text { spawned }\end{array}$ & $\begin{array}{c}\text { Fertilized Egg } \\
\text { Count }\end{array}$ \\
\hline April 1, 2017 & New moon & 21 & 2 & $1,480,000$ \\
April 9, 2017 & Full moon & 19 & 2 & 450,000 \\
August 6, 2017 & Full moon & 8 & 1 & 220,000 \\
November 17, 2017 & Full moon & 9 & 2 & 775,000 \\
\hline
\end{tabular}


Various stimuli can be applied to induce spawning of Amusium plueronectes; however, this study demonstrated successful spawning through natural spawning in relation to the lunar cycle. According to Barber and Blake (1991), one of the parameters potentially triggering spawning includes lunar phase. Lunar phase influenced the fluctuation of tide. This phenomenon allows movement of water and steering of nutrients which are very favorable for larval dispersal, development, and survival. Being conditioned in the wild, mature scallops that were brought into the hatchery responded to the lunar cue, which allowed them to spawn even under controlled condition.

The previous work of Jimenez et al. (2011) was an evidence that bivalve species is capable of spawning naturally under controlled environment. The study reported successful natural spawning of Lutraria sp., an edible and commercially important bivalve collected in Taguines Lagoon, Camiguin, Philippines. Natural spawning under laboratory conditions was attained two months after broodstock conditioning and occurred either on the first quarter, full moon, or last quarter phase of the moon. Therefore, natural spawning as spawning method of A. pleuronectes in order to produce viable larvae in the hatchery would likely be successful.

Different induction methods resulted to unsuccessful spawning of either eggs or sperms. In this study, thermal stimulation was not effective in inducing A. pleuronectes to spawn. According to Belda and Del Norte (1988), it is possible that A. pleuronectes must be "cold-conditioned" first to be receptive to thermostimulation. The study of Young (1978) reported cold-conditioning of the tropical mussel Perna viridis before inducing it to spawn by thermostimulation was found effective. However, this study showed that cold conditioning the scallops at $24^{\circ} \mathrm{C}$ for 24 hours and gradually exposing to $30^{\circ} \mathrm{C}$ was still ineffective. Possibly, a sudden decrease of temperature from the ambient $24^{\circ} \mathrm{C}$ could effectively induce $A$. pleuronectes to spawn rather than sudden increase in temperature since the spawning peak for this species was observed to occur during colder months of the year at temperatures ranging from 24.6$26^{\circ} \mathrm{C}$ in the Philippines (Belda and Del Norte, 1988). This aspect also warrants future research undertaking. Induced spawning of Amusuim pleuronectes using microalgal feeds Isochrysis galbana and Chaetoceros calcitrans was also found ineffective. Perhaps, the concentration of I. galbana and C. calcitrans was not enough to induce A. pleuronectes to spawn. Also, the study was limited from conducting further verificatory trials on this aspect. Nevertheless, the study of Breese and Robinson (1981) support this claim since concentration of marine algae used was between 2 to 2.5 million cells $/ \mathrm{ml}$ and found effective in inducing the razor clam Siliqua patula to spawn. Aji (2011) also suggested that the microalgae diet is good for conditioning bivalves and stated that the reproductive performance, gonad maturation, and the quality of broodstock are mainly influenced by food availability. Martinez et al. (2000) also reported gonadal recovery and conditioning of the Argopecten pupuratus fed by microalgae. Ostrea edulis produced more broods of larvae when fed with a mixture of microalgae (Helm et al. 1973).

In this study, sexual stimulation resulted no eggs or sperms emitted in all scallops tested while in the study of Belda and Del Norte (1988), the method was successful but not for release of eggs. Moreover, the study of Barber and Blake (1991) reported effective stimulation of spawning in C. varia using the combination of thermal stimulation with extract of gametes. The researchers of this present study speculate that the induction time and internal physiological conditions were possibly not met, hence, the failure of spawning.

The use of serotonin injection as spawning method was also ineffective. According to Aji (2011), serotonin injection is mostly used and effective to giant clams and some scallop species. Gibbons and Castagna (1984), reported six bivalve species that showed success in induced spawning using serotonin injection. These are the surf clam Spisula solidissima, the bay scallop Argopecten irradians, American oyster Crassostrea virginica, ribbed mussel Geukensia demissa, the ocean quahoq Arctica islandica, the hard clam Mercenaria mercenaria, and Mactra chinensis that have injected by serotonin in their foot also spawn (Fong et al. 1996).

Moreover, some scallops in this present study expired after serotonin injection, probably because of stress. According to Aji (2011), handling should be carefully done so as not to puncture any visceral organs of the scallop which could lead to mortality.

\subsection{Embryonic and Larval Development of Amusium pleuronectes}

The description and sequence of development after fertilization of $A$. pleuronectes larvae is presented in Figure 6 and Table 2. Development of A. pleuronectes larvae is similar to that as seen with other pectinids (Belda and Del Norte 1988; and Wang et al. 2009).

Fertilized eggs of $A$. pleuronectes appeared 
Table 2. Summary of the larval development of Amusium pleuronectes held at the MFRDC hatchery, Guiuan, Eastern Samar.

\begin{tabular}{lcc}
\hline \multicolumn{1}{c}{ Stage } & Age & Size $(\mu \mathrm{m})$ \\
\hline Fertilized egg & 0 & $54.2-62.57$ \\
Trocophore & 9 hrs. & $59.08-84.4$ \\
D-veliger & 24 hrs. & $120.37-157.07$ \\
Umbone stage & 7 days & $135.45-173.36$ \\
Pediveliger & 9 days & $160.63-375.29$ \\
Spat & 16 days & $312.41-509.48$ \\
4 -month old spat & 120 days & $4-10 \mathrm{~mm}$ \\
\hline
\end{tabular}

spherical and dark-colored, and the egg diameter ranged from 57-79 $\mu \mathrm{m}$. Embryos were left undisturbed for the first few hours. During this period, repeated cleavages led to the formation of the spherical blastula. Timing varies among species and was not determined for Amusium pleuronectes, but was determined for related species, Aequipecten irradians concentricus, to be of five hours and fifteen minutes (Sastry 1963). After nine hours, top-shaped trochophore appeared. Trochophore larvae were characterized with its apical rounded shape end and cilia.

Complete development of a straighthinge veliger appeared in less than 24 hours and is characterized by its D shape. It has two valves, visible organs, and a velum. The velum is ciliated along its outer margin, and enables the larva to swim and maintain itself in the water column. The D-veliger shell length ranged from 120.37-157.07 $\mu \mathrm{m}$.

Development of the early umbone stage reached five days after fertilization. The shape of the D-larvae gradually changed as it developed. There was a slight reduction in the hinge-length with the extension of umbones over the hinge region. At seventh day, the umbo become well developed, appearing as a conspicuous, broadly rounded knob, which ranged from $135.45-173.36 \mu \mathrm{m}$ in size. On the ninth day, pedi-veligers were seen in the culture. Pediveliger larvae developed a functional foot, which can extend when brought into contact with the substrate. The shell length of pedi-veliger that was observed in the laboratory ranged from 160.63-375.29 $\mu \mathrm{m}$. On the 16th day, spats appeared at the bottom of the tanks and can be seen visibly as minute fan-like, white colored shells. The shell length of these spats ranged from 312.41-509.48 $\mu \mathrm{m}$ and have foot used for crawling at the bottom of the tank.
Different batches of larvae from different spawning events were monitored, and the development of larvae varies in each spawning. Spats produced from the successful spawning lasted until four months in the hatchery with shell length ranged from $4 \mathrm{~mm}$ to $10 \mathrm{~mm}$, while other batches of larvae were until pediveliger stage only or some died as early as D-larvae. Therefore, further study and experimentation under improved conditions is necessary and crucial. Factors like stocking density, rearing temperature, and microalgae diets affect optimal growth, survival, and development of Amusium pleuronectes larvae under control conditions are still for investigation.

\subsection{Larval Rearing}

The majority of larvae in every treatment, except for 800 larvae/L stocking density, developed into spat after one month. Mass mortality was observed in 800 larvae/L on day 18 pedi-veliger stage. The survival rates ranged from $0.00 \pm 0.00 \%$ to $0.04 \pm 0.03 \%$ (Figure 7 ) and significant differences was observed among 200 larvae/L, 300 larvae/L, and 500 larvae/L ( $<<0.05)$.

High mortality in larvae may be due to poor water quality or disease. This has been observed in the setup for 800 larvae/L stocking density, wherein contamination of protozoans was seen. This was also similar in the previous work of Avila et al. (1997) where the stocking density of $H$. crassicornis larvae reared at 0.5-4 individuals/mL showed decreased survival but a density of 15 larva/mL resulted in larval mortality. Moreover, according to Orensanz et al. (1991), the decreased survival rate at high densities is possibly due to food and oxygen depletion, predation, or other environmental stresses. 

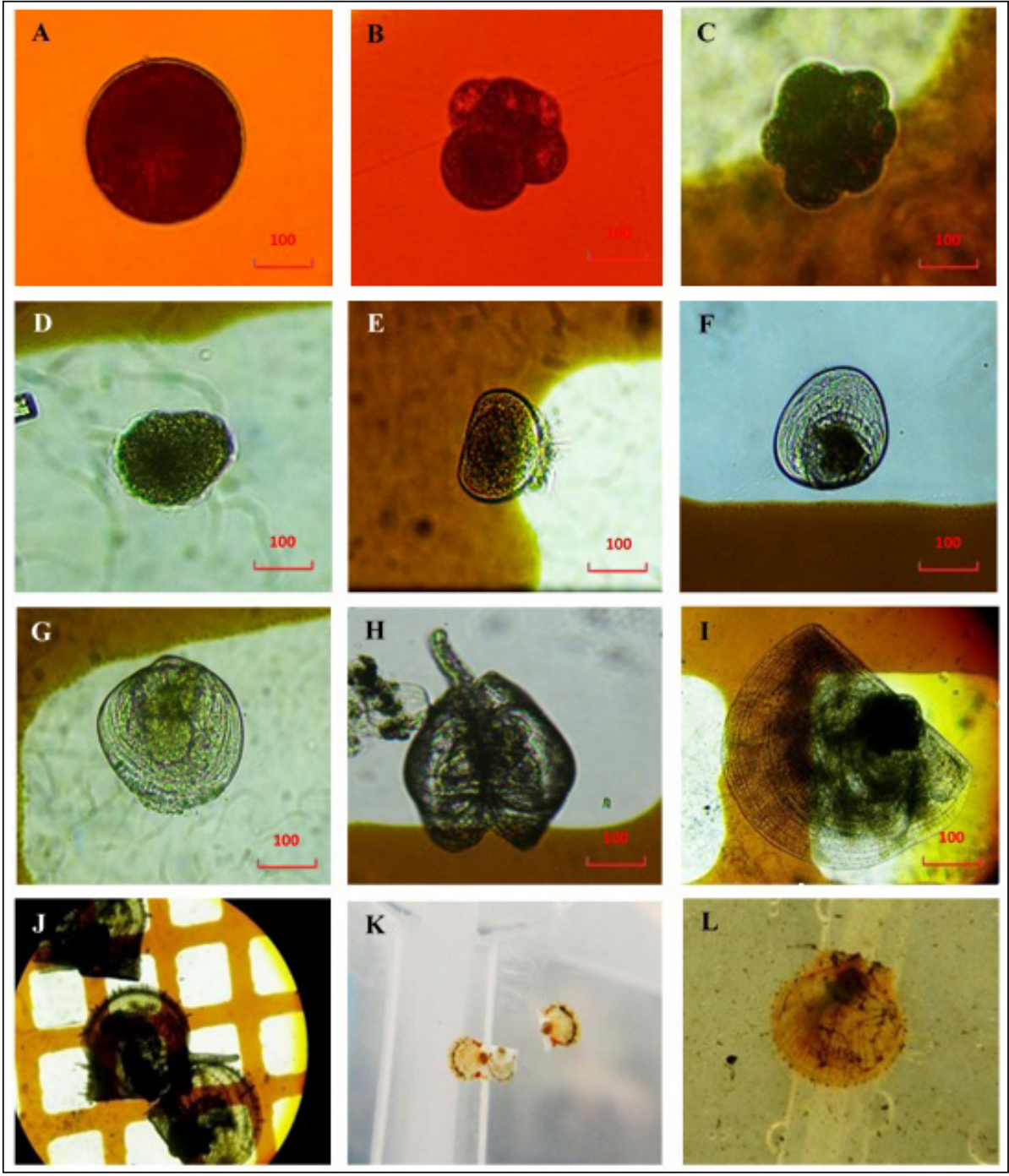

Figure 6. Embryonic and larval development of Amusium pleuronectes: (A) fertilized egg with the expulsion of polar body; (B) 4-cell embryo; (C) multi-cell stage; (D) trocophore larva; (E) Straight-hinge larva; (F) eyespot larva or the umbo stage; $(\mathrm{G})$ early pediveliger larva; $(\mathrm{H})$ hinge of pediveliger stage larva; (I) spat on day 16; (J) one-month old spat; (K) two-month old spat; and (L) $10 \mathrm{~mm}$ 4-month old spat. Scale bar: $100 \mu \mathrm{m}$

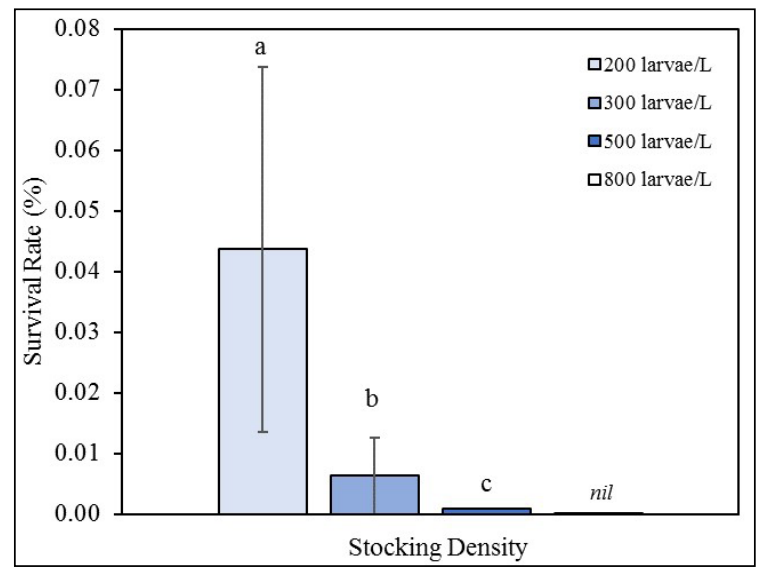

Figure 7. Mean survival rate of Amusium pleuronectes larvae at different stocking densities. Note: Mean $( \pm \mathrm{SE})$ values of different stocking densities with different letters show significant difference $(\mathrm{p}<0.05)$. 
In this study, algal concentrations were adjusted accordingly with different larval densities to ensure larvae received an equal diet. Thus, food is not a limiting factor in the survival of larvae. The mass mortality of larvae in 800 larvae/L stocking density could be possibly due to abrupt sinking of larvae. Unremoved dead larvae could contribute to the contamination of protozoans and build-up of bacteria in the rearing container. Therefore, water exchange management and other factors were taken into strict consideration in rearing the larvae. Being in static water system, culture medium must be renewed to prevent build-up of bacteria or other metabolites. The experimental densities tested in the present study cannot conclude or recommend a density-dependent survival rate. Thus, it is suggested that in laboratory conditions, water treatment used in the experiment should be considered such as sand filtered, UV treatedm and chlorinated seawater.

\section{C O N C L US I O N}

Generally, preliminary data and information were presented in the attempt of breeding and larval rearing of Amusium pleuronectes in Guiuan, Eastern Samar. These include broodstock conditioning, spawning technique, larval development stage, and larval rearing. A. pleuronectes is best conditioned in a flow-through water system without substrate at water temperature of $26-29^{\circ} \mathrm{C}$. The suitable microalgal diets were Isochrysis galbana and Chaetoceros calcitrans at 7,388,888 cell. $\mathrm{min}^{-1}$ given twice daily. These promoted higher survival of scallop in the hatchery, but required time of conditioning to reach spawning readiness is still unknown. Moreover, A. pleuronectes spawn naturally, and the subsequent development of the larvae under laboratory condition was recorded up to 4-month old juveniles with very low survival rate. Further studies on the induction of spawning is warranted since the present study was hindered with limited number of experimental trials. Moreover, different aspects may also be considered in the future to improve larval rearing techniques.

\section{A C K N O W L E D G M EN T}

The authors are grateful for the support of the National Fisheries Research and Development Institute and the technical assistance of the staff of Guiuan Marine Fisheries Development Center (GMFDC) and Guiuan Marine Research Development Center (GMRDC), including Mr. Mheljay D. Burlaza, Clifford
O. Relator, Michael Gayoso, Alicia Lacdo-o, and Denis R. Salameda. Also, the authors extend their sincere gratitude to the agriculture technicians of the Local Government Units of Biliran, Biliran and Mayorga, Leyte for their logistic help.

\section{R E F E R E N C E S}

Aji LP. 2011. Review: Spawning Induction in Bivalve. Jurnal Penelitian Sains, Vol. 14, p. 33-36.

Avila C, Grenier S, Tamse CT, Kuzirian AM. 1997. Biological factors affecting larval growth in the nudibranch mollusk Hermissenda crassicornis (Eschscholtz, 1831). J. Exp. Mar. Biol. Ecol. 218: 243-262.

Barber BJ, Blake NJ. 1991. Reproductive Physiology, In: S.E. Shumway (Ed.), Scallops: Biology, Ecology and Aquaculture. Elsevier, Amsterdam, pp. 394-407.

Belda CA, Del Norte AGC. 1988. Notes on the Induced Spawning and Larval rearing of the Asian Moon Scallop, Amusium pleuronectes (Linne), in the Laboratory. Aquaculture. Vol. 72, pp. 173-179.

Breese WP, Robinson A. 1981. Razor clams, Siliqua patula (Dixon): Gonadal development, induced spawning and larval rearing. Aquaculture. 22: 27-33.

Bricelj VM, Shumway CE. 1991. Physiology: Energy Acquisition and Utilisation. In: SE.

Shumway (Editor), Scallops: Biology, Ecology and Aquaculture. Elsevier, Amsterdam. pp. 305-346.

Cabacaba NS, Salamida MT. 2017. Distribution, Abundance and Reproductive Biology of Asian moon Scallop, Amusium pleuronectes, in Eastern Visyas Philippines (unpublished data).

Chaitanawisuti N, Menasveta P. 1992. Preliminary studies on breeding and larval rearing of the Asian moon scallop (Amusium pleuronecres). J. Aquaculture Trop., 7: 205-218.

Creswell L. 2010. Phytoplankton Culture for Aquaculture Feed. Southern Regional Aquaculture Center, No. 5004. 
Del Norte AGC. 1988. Some aspects of the growth, recruitment, mortality and reproduction of the Asian moon scallop Amusium peuronectes (Linne) in Lingayen Gulf, Philippines. Ophelia. 29(2): 153-168. DOI: 10.1080/00785326.1988.10430826.

Del Norte AGC. 1986. Some aspects of the growth, recruitment, mortality and reproduction of the Asian moon Scallop Amusium pleuronectes (Linne) in Lingayen Gulf, Philippines. Master's Thesis, University of The Philippines (Diliman), $114 \mathrm{p}$.

Epifanio CE. 1979. Growth in bivalve molluscs: nutritional effects of two or more species of algae in diets fed to the American oyster Crassostrea uirginica (Gmelin) and the hard clam Mercenaria CL. Aquaculture. 18: 1-12.

FAO. 2001. Fishing Gear types. Bottom pair trawls. Technology Facts Sheets. FAO Fisheries and Aquaculture Department [internet]. Rome. Updated 13 September 2001. [Cited 28 September 2018]. http://www.fao.org/fishery/

Fong PP, Deguchi R, Kyozuka K. 1996. Serotonergic ligands induce spawning but not oocyte maturation in the bivalve Mactra chinesis from central Japan. Biol. Bull. Vol. 191, p. 27-32.

Gabral-Llana ME. 1980. A Contribution to the Biology of the Asian moon scallop, Amusium pleutronectes (Linnaeus, 1758). Master's Thesis, University of The Philippines.

Gibbons MC, Castagna M. 1984. Serotonin as an inducer of spawning in six bivalve species. Aquaculture 40: 189-190.

Habe T. 1964. Notes on the species of the genus Amusium (Mollusca). - Bull. natn. Sci. Mus. Tokyo 7(1): 1-5.

Helm MM, Bourne N, Lovatelli A. 2004. Hatchery culture of bivalves. A practical manual. FAO Fisheries Technical Paper. No. 471. Rome, FAO. $177 \mathrm{p}$.

Helm MM, Holland DL, Stephenson RR. 1973. The effect of supplementary algal feeding of a hatchery breeding stock of Ostrea edulis L. on larval vigour. J. Mar. Biol. Assoc.UK 53. pp. 673-684.

Jimenez CR, Dejarme HE, Jimenez JU, Gaid RD. 2011. Habitat Characteristics, Spawning, Relative Fecundity and Larval Development of Lutraria sp. (Bivalvia: Mactridae). Journal of Environment and Aquatic Resources. 2: (1120).

Kinne O. 1970. Temperature - animals, invertebrates. In: 0. Kinne (Ed.). Marine Ecology, a Comparative Treatise on Life in Oceans and Coastal Waters Environmental Factors. WileyInterscience. New York. Volume 1. pp. 821-995.

Liu B, Dong B, Tang B, Zhang T, Xiang Z. 2006. Effect of stocking density on grow settlement and survival of clam larvae, Meretrix meretrix. Aquaculture 258: 344-349.

Llana MEG. 1983. Size composition, occurrence, distribution and abundance of scallops in the Visayan Sea. - Philipp. J. Fish. 16(2): 75-94.

Llana MEG, Aprieto VL. 1980. Reproductive biology of the Asian moon scallop Amusium pleuronectes. Fish. Res. J. Philipp., 2:1-10.

Martinez G, Aguilera C, Mettifogo L. 2000. Interactive effects of diet and temperature on reproductive conditioning of Argopecten purpuratus broodstock. Aquaculture. 183: 149-159.

Morton B. 1980. Swimming in Amusium pleuronectes (Bivalvia: Pectinidae). Journal of Zoology 190: 375-404.

Nell JA, O'Connor WA. 1991. The evaluation of fresh algae and stored algal concentrates as a food source for Sydney rocks, Saccostrea commercialis (Iradale and Roughley) larvae Aquaculture. 99: 277-284.

Orensanz JM, Parma AM, Iribarne OO. 1991. Population dynamics and management of natural stocks. In: Shumway, S.E. (Ed.), Scallops: Biology, Ecology and Aquaculture. Elsevier, New York, pp. 625-713. 
Rice MA, Rheault RR, Perez MS, Perez VV. 1994. Wang Y, Ye L, Yang Q, Chen X, Wen W, Wu K. 2009. Experimental Culture and Particle Filtration by Asian Moon Scallops, Amusium pleuronectes. Asian Fisheries Science 7: 179-185. A preliminary research on artificial breeding of the Asian moon scallops Amusium pleuronectes. South China Fisheries Sciences 5(1): 36-41.

Sastry AN. 1963. Reproduction of the bay scallop, Young AL. 1978. Larval and post-larval biology of the Aequipected irridiuns Lamarck. Biol. Bull (Woods Hole) 125: 146-153. tropical green mussel Smarugdinus Chemnitz. Master's Thesis, University of The Philippines (Diliman), $114 \mathrm{p}$. 


\section{APPENDIX A}

Table 3. Daily food ration for the larvae at different stocking densities during the experimental period.

\begin{tabular}{ccccc}
\hline \multirow{2}{*}{ Day No. } & \multicolumn{4}{c}{ Daily algal ration (x 104 cells/mL) } \\
\cline { 2 - 5 } & 200 larvae per Liter & 300 larvae per Liter & 500 larvae per Liter & 800 larvae per Liter \\
\hline Day 0 & 1.0 & 2.0 & 4.0 & 8.0 \\
Day 1 & 2.0 & 4.0 & 8.0 & 16.0 \\
Day 2 & 3.0 & 6.0 & 12.0 & 24.0 \\
Day 3 & 4.0 & 8.0 & 16.0 & 32.0 \\
Day 4 & 5.0 & 10.0 & 20.0 & 40.0 \\
Day 5-30 & 6.0 & 12.0 & 24.0 & 48.0 \\
\hline
\end{tabular}

\section{APPENDIX B}

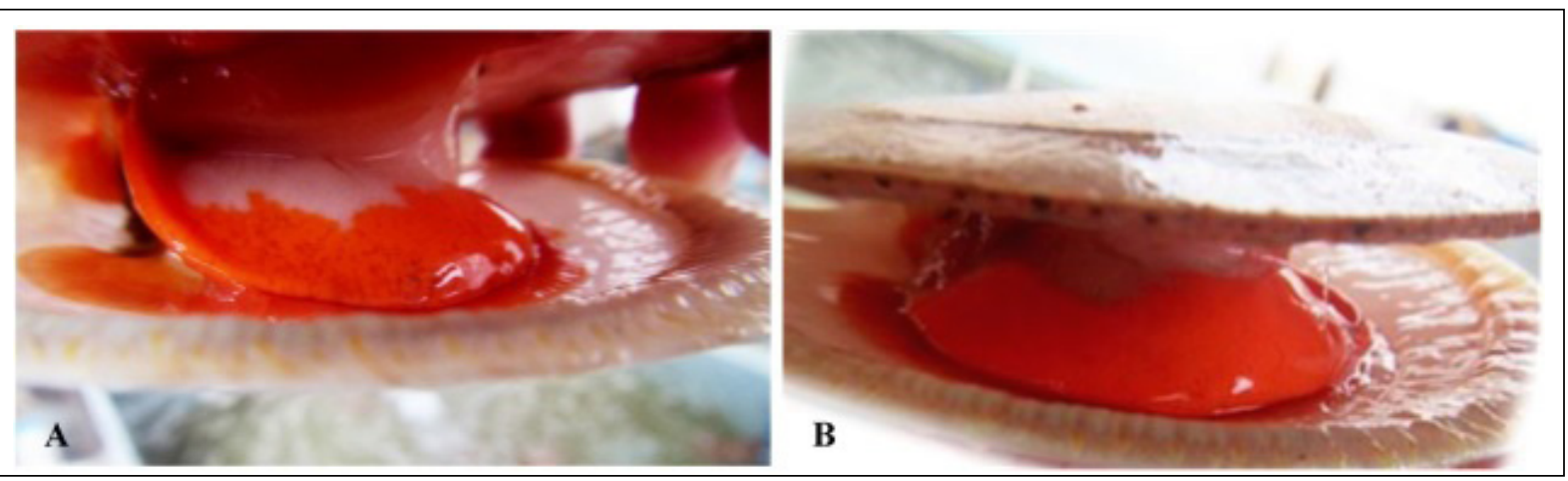

Figure 8. Gonad of Asian moon scallop reveals a bright orange ovary and cream-colored testes. A) Partially spawned gonads; B) Gonad in its mature stage

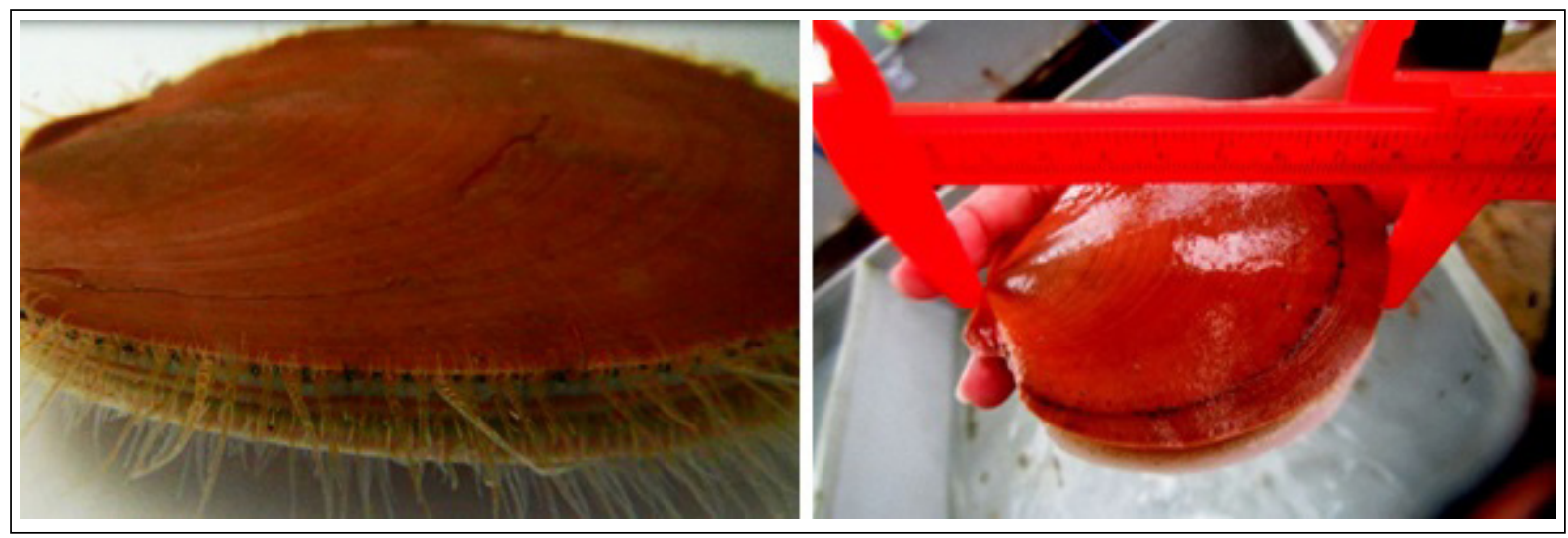

Figure 9. Asian moon scallop with well-formed shells and mantles extending to the shell margin and shell length ranged from 80-90 mm. 